\title{
Effects of Baby Massage in Reducing Body Temperature after Combined Diptheri Pertussis Tetanus/Hepatitis B Immunization
}

\author{
Linda Meliati, Ni Putu Karunia Ekayani, and Suwanti
}

\section{ABSTRACT}

Background: Side effects that may often occur after immunization include fever in infants after to combined Diptheri Pertusis Tetanus/Hepatitis B (DPT/HB) vaccine. Fever in infants or toddlers is a case that cannot be ignored because it can interfere with the comfort and development of infants and toddlers.

Objectives: This research aims to analyze the effects of baby massage in lowering body temperature among babies given combined DPT/HB immunization.

Material and Methods: It is a quasi-experiment using one intervention group. The population and sample are babies aged 2-5 months visiting the Work Area of Puskesmas Lombok Barat in Indonesia that meet inclusion criteria. Baby massage was administered in the morning and in the afternoon for 5 days, with the first 2 days prior to combined DPT/HB immunization 1, the second 1 day at the time of immunization, and the last 2 days after immunization. The same treatment was also carried out for combined DPT/HB immunization 2. Prior and after massage, baby temperatures were measured at the axila using a digital thermometer, with the results put in an observation sheet (graph). Body temperature measurement was observed for 2 months. Data gathered were then tested using non-parametric test (Wilcoxon).

Results: there is reduction in body temperature among babies given combined DPT/HB immunization 1 and combined DPT/HB immunization 2. Babies given combined DPT/HB immunization 1 had average body temperature of $0,2 \pm 0.18{ }^{\circ} \mathrm{C}$ in the morning and $0,21 \pm 0.25{ }^{\circ} \mathrm{C}$ in the afternoon. Meanwhile, babies given combined DPT/HB immunization 2 had average body temperature of $0,26 \pm 0.19{ }^{\circ} \mathrm{C}$ in the morning and $0,2 \pm 0.23{ }^{\circ} \mathrm{C}$ in the afternoon. Effect of massage in reducing body temperature among babies given combined DPT/HB immunization 1 is at $(p<0.005)$ and at $(\mathbf{p}<0.005)$ for combined DPT/HB immunization 2.

Conclusion: massage can be performed before or after babies are immunized with combined DPT/HB to lower their body temperature.

Keywords: baby massage; diphtheria pertussis tetanus; hepatitis B; immunization.

\section{INTRODUCTION}

Immunization is estimated to prevent 2.5 million cases of child mortality per year across the world [1]. In Indonesia, immunization is a program of national policy. Immunization is given for the purpose of reducing the number of sickness and mortality among babies by controlling Preventable Diseases such as Tuberculosis (TB), diphtheria, pertussis (respiratory disease), smallpox, tetanus, polio and hepatitis B. Immunization Program is very important to obtain immunity at community level [2]. Combined DPT/HB immunization is administered 3 times, i.e., at 2 months (combined DPT/HB 1), at 3 months (combined DPT/HB 2) and at 4 months (combined DPT/HB 3) with a minimum interval of 4 weeks each. among $6.8 \%$ toddlers [3].
Submitted : March 5, 2021

Published : April 05, 2021

ISSN: 2593-8339

DOI: $10.24018 /$ ejmed.2021.3.2.753

Linda Meliati*

S. Si. T., M. Kes

Poltekkes Kemenkes Mataram,

Indonesia.

(e-mail: meliatilinda@gmail.com)

Ni Putu Karunia Ekayani

SST., M. Kes

Poltekkes Kemenkes Mataram,

Indonesia

(e-mail: putuekayani78@yahoo.co.id)

Suwanti

SST., M. Kes

Poltekkes Kemenkes MataramIndonesia.

(e-mail: wanti_1205@yahoo.co.id)

*Corresponding Author

The scope of complete immunization in Indonesia shows significant improvements from $41.6 \%$ (2007) to $59.2 \%$ (2013). However, $32.1 \%$ of babies are still given incomplete immunization, while $8.7 \%$ are not immunized at all, with reasons including fear of fever, possible other illnesses, believes in the family, distant immunization location and not being aware of where to immunize or simply no time to do it. Data from Basic Health Research in 2013 show that of those $91.3 \%$ immunized, 33.4\% experienced Adverse Event Following Immunization (AEFI). Syndromes reported include skin redness and inflammation, as well as high fever

Despite its benefits, immunization also comes with side effects known as Adverse Event Following Immunization. One of these side effects is fever after the administration of 
combined DPT/HB vaccine. Some parents also make this fever that happen post immunization as an excuse of not getting their babies immunized [4]. Fever is a natural bodily reaction as a self-defense mechanism against infection. In this case, it is caused by a component of DTwP vaccine. Administration of DTwP vaccine may cause high fever, seizure and shock that makes prevention a necessity [5], [6]. A research in Korea revealed that hindrances of vaccination include doubts about vaccines, personal circumstances, lack of information, and misleading classification. Doubts against vaccines is the most significant factor that hinders vaccination. It was also found that factors hindering vaccination change over time and they affect groups differently [7].

Midwives may take measures to lower a baby's body temperature and giving massage (touch therapy) is one of those. This only makes sense as touch therapy comes with the benefit of lowering body temperature. This is in line with a research showing that touch therapy increases the temperature of premature babies being treated. On the other hand, it is also found to lower body temperature among other babies [8], [9]. Massage therapy may result in beneficial physiological changes that can be scientifically measured, including measurement of levels of saliva cortisol, plasma cortisol using radio-immunoassay, stress hormone (catecholamine), urine, and EEG (electro encephalogram) examination [10]. Baby massage can increase body weight, improve emotional and social development, facilitate more stable temperament, and reduce the level of stress hormone in urine [11]. Touch therapy in the form of massage can increase the activity of serotonin neurotransmitter, i.e., improving the capacity of receptor cells in binding stress hormone. Less stress hormone leads to improved stamina.

Data from the Provincial Health Department of West Nusa Tenggara on AEFI in 2012, the city of Mataram reported 3 cases, West Lombok also had 3 cases, Central Lombok had 1 case, Sumbawa had 1 case and Bima had 1 case of AEFI such as inflammation on injection point of the skin, high fever, seizure, redness, decreased consciousness, anaphylactic shock, vomiting, etc. [12]. Data on immunization coverage for combined DPT/HB 1 in was at $99.4 \%$ in 2013 and at $98.2 \%$ in 2014. Immunization coverage for combined DPT/HB1 in West Lombok in 2013 was at $96.2 \%$ and at $98.7 \%$ in 2014 [13].

This research was carried out in Work Area of Puskesmas Lombok Barat, which is one of 8 regencies in West Nusa Tenggara in Indonesia. Work Area of Puskesmas Lombok Barat consists of 17 Puskesmas, with immunization coverage for combined DPT/HB 1 as follows: Puskesmas Meninting (95.1\%), Puskesmas Gunungsari (96.8\%) and Puskesmas Kediri $(95.1 \%)$, which represent highest coverage compared to the other Puskesmas such as Puskesmas Lingsar (89\%), Puskesmas Sigerongan (91.9\%), and Puskesmas Penimbung $(84.5 \%)$ [14]. This research aims to analyze the effects of baby massage in lowering body temperature among babies given combined DPT/HB immunization.

\section{MATERIAL AND Methods}

This is an observational and non-randomized research. The population is babies aged 2-5 months visiting the Work Area of Puskesmas Lombok Barat in Indonesia during data collection period from July-September 2016. Samples are taken from this population. Analysis using statistical test for quantitative research requires a minimum of 30 samples [15]. Therefore, samples in this research are 30 babies aged 2-5 months taken using purposive sampling method in line with inclusion criteria. Inclusion criteria: babies aged 2-5 months, already given BCG immunization, healthy and do not have any contra-indication against immunization given, have not been given combined DPT/HB 1, combined DPT/HB 2 or combined DPT/HB 3 immunization. Exclusion criteria: babies who are sick and have congenital abnormalities such as heart condition, and those who have been given combined DPT/HB 1, combined DPT/HB 2, or combined DPT/HB 3.

Data were gathered from 15 July through 30 September 2016 in Work Area of Puskesmas Lombok Barat in Indonesia (Puskesmas Gunungsari, Puskesmas Kediri and Puskesmas Meninting). Data gathered were based on observations made. Data were gathered by first determining samples according to inclusion criteria. They were then given intervention in the form of 5-day massaging; 2 days prior to immunization, 1 day during immunization, and 2 days after immunization. This same intervention was applied for both combined DPT/HB 1 and DPT/HB 2 immunizations. The researchers conducted massaging twice a day; in the morning and in the afternoon before babies were given a bath. This regime was implemented for 2 months.

This research involves samples of babies aged 2-5 months who have been given BCG, combined DPT/HB 1, and subsequently combined DPT/HB 2 immunizations, with the latter two given a 4-week interval. Prior to massaging, babies were screened for anamnesis, contra indication against massaging and combined DPT/HB 1 and combined DPT/HB 2 immunizations, to ensure their well-being. Babies who failed this screening were not given massage, while those otherwise were given massage by Diploma IV midwifery students who were in their 7 th semester. These students have been given baby massage training themselves. Meanwhile, combined DPT/HB 1 and combined DPT/HB 2 immunizations were performed by midwives at the Puskesmas where this research took place, with the researchers serving as observers.

Prior to massaging, parents were informed about research procedure and its purpose, and they then signed informed consent to make their babies respondents of this research. The pretest stage measured differences in baby temperature at the axila using Omron digital thermometer. This was carried out before massaging in the morning and in the afternoon over 2 days prior to combined DPT/HB 1 and combined DPT/HB 2 immunizations, with a single massage lasting 15 minutes. After massaging, babies' temperatures were re-measured and observed values were recorded in the observation sheet (graph).

On the 3rd day prior to combined DPT/HB 1 immunization, babies' body temperatures were still measured in the morning and in the afternoon. This treatment was also applied for combined DPT/HB 2 immunization, which was given after an interval of 4 weeks. The posttest stage also 
measured differences in babies' body temperature after intervention (massaging) using the same method and procedure as during pretest. These posttest measurements were made up to 2 days after combined DPT/HB 1 and combined DPT/HB 2 immunizations. Observed values were also put into observation sheet (graph).

Data analysis was performed using SPSS 16 for Windows (licensed copy owned by TEAM QX $6^{\text {th }}$ Birthday, 1337). The data analysis method used was univariate analyses for values of frequency distribution, minimum, maximum, mean, and standard deviation. Prior to bivariate analysis, data normality test using Shapiro-Wilk test was performed. Results from this showed that data were not normally distributed that subsequent bivariate analysis employed the Wilcoxon statistical test.

\section{RESULT}

Table I shows that there are more female respondents (17 babies/56.7\%) than male respondents (13 babies/43.3\%). It also shows that in terms of age, most respondents are 2 months old (18 babies/60\%), and only 1 baby is 5 months old $(3.3 \%)$.

Results show reduction in body temperature among babies given combined DPT/HB 1 immunization who were treated with massaging (Table II). Decrease in body temperature among babies given combined DPT/HB 1 immunization is an average of $0.2 \pm 0.18^{\circ} \mathrm{C}$ in the morning and $0.21 \pm 0.25^{\circ} \mathrm{C}$ in the afternoon.

Results from Wilcoxon signed-rank test show effects of massage on decreasing body temperature among babies given combined DPT/HB 1 immunization. Values for babies given massage are $p=0.000$ in the morning, $p=0.000$ in the afternoon with $\alpha 0.05$ (Table II).

Table III shows results in terms of reduction in body temperature among babies given combined DPT/HB 2 immunization who were treated with massaging. The decrease in body temperature among babies given combined DPT/HB 2 immunization is an average of $0.26 \pm 0.19^{\circ} \mathrm{C}$ in the morning and $0.2 \pm 0.23{ }^{\circ} \mathrm{C}$ in the afternoon.

Results from Wilcoxon signed-rank test (Table III) show effects of massage on decreasing body temperature among babies given combined DPT/HB 2 immunization. Values for babies given massage are $\mathrm{p}=0.005$ in the morning and $\mathrm{p}=$ 0.000 in the afternoon with $\alpha 0.05$.

\begin{tabular}{|c|c|}
\hline Characteristics & Frequency (n) \\
\hline \multicolumn{2}{|l|}{$\overline{\text { Gender }}$} \\
\hline Male & $13(43.3)$ \\
\hline Female & $17(56.7)$ \\
\hline \multicolumn{2}{|l|}{ Age (month) } \\
\hline 2 & $18(60)$ \\
\hline 3 & $7(23.4)$ \\
\hline 4 & $4(13.3)$ \\
\hline 5 & $1(3.3)$ \\
\hline
\end{tabular}

TABLE II: BODY TEMPERATURE OF BABIES GIVEN COMBINED DPT/HB IMMUNIZATION 1, BEFORE AND AFTER MASSAGE IN THE MORNING AND IN THE AFTERNOON

\begin{tabular}{|c|c|c|c|c|c|c|c|}
\hline \multirow{2}{*}{ Variable } & \multicolumn{3}{|c|}{ Before given a massage } & \multicolumn{3}{|c|}{ After given a massage } & \multirow{2}{*}{$\mathrm{p}$-value } \\
\hline & $\operatorname{Max}$ & Min & Mean \pm SD & Max & Min & Mean \pm SD & \\
\hline $\begin{array}{l}\text { Body temperature in } \\
\text { the morning }\left({ }^{\circ} \mathrm{C}\right)\end{array}$ & 37 & 35.90 & $36.53 \pm 0.26$ & 36.70 & 36 & $36.33 \pm 0.18$ & 0.000 \\
\hline $\begin{array}{l}\text { Body temperature in } \\
\text { the afternoon }\left({ }^{\circ} \mathrm{C}\right)\end{array}$ & 37.30 & 36.10 & $36.66 \pm 0.28$ & 37.02 & 35.94 & $36.45 \pm 0.25$ & 0.000 \\
\hline
\end{tabular}

TABLE III: BODY TEMPERATURE OF BABIES GIVEN COMBINED DPT/HB IMMUNIZATION 2, BEFORE AND AFTER MASSAGE IN THE MORNING AND IN THE AFTERNOON

\begin{tabular}{cccccccc}
\multicolumn{4}{c}{ BEFORE AND AFTER MASSAGE IN THE MORNING AND IN THE AFTERNOON } & \multicolumn{3}{c}{ Before given a massage } & \multicolumn{3}{c}{ After given a massage } & p-value \\
\hline \hline Variable & Max & Min & Mean \pm SD & Max & Min & Mean \pm SD & \\
\hline $\begin{array}{c}\text { Body temperature in } \\
\text { the morning }\left({ }^{\circ} \mathrm{C}\right)\end{array}$ & 37 & 36 & $36.63 \pm 0.49$ & 36.80 & 36.10 & $36.37 \pm 0.19$ & 0.005 \\
$\begin{array}{c}\text { Body temperature in } \\
\text { the afternoon }\left({ }^{\circ} \mathrm{C}\right)\end{array}$ & 37.20 & 36 & $36.63 \pm 0.25$ & 37.02 & 35.86 & $36.43 \pm 0.23$ & 0.000 \\
\hline \hline
\end{tabular}

\section{DISCUSSION}

Based on the results of the study, the number of respondents was mostly female because at the time of taking the sample it was nonprobability sampling with a purposive technique according to the inclusion criteria and the age of most respondents was 2 months old because the requirements for combined DPT/HB immunization started at the age of 2 months, combined DPT/HB immunization is given 3 times, namely at the age of 2 months of the baby of the vaccine given combined DPT/HB 1 immunization, Polio 2, the age of the baby of 3 months of the vaccine given combined DPT/HB 2 immunization, Polio 3 and the age of the baby 4 months of the vaccine given combined DPT/HB 3 immunization, Polio 4 [16].

The results showed that most of the respondents experienced an increase in body temperature decrease after being given intervention (baby massage) in babies who were immunized with combined DPT/HB 1 immunization in the morning, namely 26 respondents $(86.67 \%)$, and 4 respondents $(13.33 \%)$ did not experience a decrease in body temperature (body temperature increased), while in the afternoon most respondents experienced an increase in body temperature decrease as many as 23 respondents $(76.67 \%)$, and 7 respondents $(23.33 \%)$ did not experience a decrease in body temperature (body temperature has increased).

Likewise, for babies who were given combined DPT/HB 2 immunization, most of the respondents experienced an increase in the decrease in body temperature after being given intervention (baby massage) in the morning of 19 respondents (63.34\%), 11 respondents $(36.66 \%)$ did not experience a decrease. body temperature (body temperature has increased), while in the afternoon most of the respondents experienced an increase in body temperature decline as many 
as 26 respondents $(86.67 \%), 4$ respondents (13.33\%) did not experience a decrease in body temperature (body temperature increased).

The factor that causes the baby's body temperature to increase is due to the fact that under normal circumstances body temperature fluctuates throughout the day, in the morning it can drop $0.5{ }^{\circ} \mathrm{C}$ below normal, while in the afternoon it can rise $0.5^{\circ} \mathrm{C}$ above normal. The results of this study are similar to the results of other studies, namely toddlers are vulnerable to changes in vital signs, namely there is a decrease in vital signs in newborns before and after being given touch therapy with an average value showing a decrease, effective touch therapy provides benefits. relaxation thereby reducing the basal metabolic rate and decreasing vital signs [17].

In this study, after the baby was immunized with DPT/ HB Kombo1, a fever occurred. The temperature of fever $(>37.5$ ${ }^{\circ} \mathrm{C}$ ) was 3 people and the highest was $37.8^{\circ} \mathrm{C}$ as many as 1 person, but at the time of combined DPT/HB 2 immunization none of them had fever $\left(\leq 37.5^{\circ} \mathrm{C}\right)$. The side effect of the combined DPT/HB immunization is fever. Symptoms of Post-Immunization Follow-Up (AEFI) after being given the Diptheri Pertussis Tetanus (DPT) immunization that most often appear is fever. Fever occurs on the second day after immunization [18]. Fever is a natural reaction from the body as a defense mechanism against infection because fever is only a symptom and is caused by a component of the DTwP vaccine. Giving the DTwP vaccine can cause high fever, seizures and shock, so it is very important to take precautions [5], [6].

The results of this study are similar, namely that the Kangaroo Method Treatment (PMK) causes the baby to have fever due to higher immunization compared to those not given Kangaroo Method Treatment (PMK) [19].

This only makes sense as touch therapy comes with the benefit of lowering body temperature. This is in line with a research showing that touch therapy increases the temperature of premature babies being treated. On the other hand, it is also found to lower body temperature among other babies [8], [9]. Massage therapy may result in beneficial physiological changes that can be scientifically measured, including measurement of levels of saliva cortisol, plasma cortisol using radio-immunoassay, stress hormone (catecholamine), urine, and EEG (electro encephalogram) examination [10]. Baby massage can increase body weight, improve emotional and social development, facilitate more stable temperament, and reduce the level of stress hormone in urine [11]. Touch therapy in the form of massage can increase the activity of serotonin neurotransmitter, i.e., improving the capacity of receptor cells in binding stress hormone. Less stress hormone leads to improved stamina.

The results of this study found that there was an effect of baby massage on decreasing body temperature in babies who were immunized with combined DPT/HB 1 immunization both in the morning and in the evening and there was also an effect of baby massage on decreasing body temperature in babies who were given combined DPT/HB 2 immunization.

The results of this study are similar to several studies that have been conducted previously by other researchers in other countries and Indonesia. Breastfeeding can reduce the incidence of fever after DTwP-1 immunization [20].
Research in Kendari City conducted in 2018 concluded that there is a relationship between giving DPT immunization to changes in body temperature in infants aged 3-12 months [21]. The results of other studies showed a difference between body temperature in infants with fever after kangaroo treatment in the intervention group and the control group [19].

Results from this research are similar to those of other researches carried out abroad and in Indonesia. Breastfeeding lower the rate of fever occurrences after DTwP-1 immunization [20]. A research carried out in Kendari in 2018 concluded that there is a relationship between administration of DPT immunization and changes in body temperature among babies aged 3-12 months [21]. Another research revealed differences in body temperature among babies given kangaroo care between the intervention and the control group [19].

A research in Brazil concludes that massage therapy improves psychomotor development as well as promoting growth [22]. A study in Iran in 2015 evaluated the effects of baby massage on the level of transcutaneous bilirubin and stool frequency of term newborn. Results show that babies given massage have lower level of transcutaneous bilirubin compared to control group [23].

Another research conducted from June 2008 - February 2010 at the Midwifery Clinic of Atatürk Hospital revealed the effects of baby massage on the bond between the mother and her baby [24]. A research conducted in 2010 concluded encouraging relationships between massage therapy and increase in body weight [25] and even massage independently performed by mothers proved to help with growth and development of babies with Low Birth Weight history [26]. This study also revealed a relationship between health education and the practice of massage therapy by mothers for their babies [27]. A research concluded that baby massage affects decrease in cortisol level and improve sleep quantity among babies hospitalize at Marwah ward of RSU Haji Surabaya [28].

\section{CONCLUSION}

This research recommends that health facilities administering immunization should give baby massage to babies prior to immunization, especially combined DPT/HB immunization. They should also campaign for baby massage to the community, especially for mothers of newborns or those having babies and are about to take their babies for immunization. It is expected that this campaign will encourage those mothers to perform baby massage themselves in order to reduce possible change of sickness among babies and to decrease body temperature of their babies before and after immunization. Therefore, the problem of fever that is feared most by mothers upon combined DPT/HB immunization for their babies can be mitigated.

\section{ACKNOWLEDGMENT}

The writers wish to thank all parties who have contributed to this research. We are especially indebted to the Director of Poltekkes Kemenkes Mataram, Head of West Lombok 
Regional Health Agency, Heads of Puskesmas Gunungsari, Puskesmas Meninting, and Puskesmas Kediri, as well as all midwives and Diploma IV students who have made their invaluable contributions.

\section{FUNDING SOURCE}

This research was funded by Skema Hibah Kompetisi (Competition Grant Scheme) of Daftar Isian Pelaksanaan Anggaran/DIPA (Checklist of Budget Use) from Poltekkes Kemenkes Mataram for the 2016 fiscal year, Number SP DIPA-024.12.2.632270/2016 dated 7 December 2015, Activity Code 5034.047, Research for Lecturers.

\section{ETHICAL CLEARANCE}

An ethical consent for this research was obtained from the ethical commission for health research of the Faculty of Medicine of Universitas Mataram Number: 66/UN 18.8/ETIK.2016. Informed consent was signed by all respondents prior to administration of baby massage for samples that meet inclusion criteria.

\section{REFERENCES}

[1] Burton A, Monasch R, Lautenbach Barbara et al. WHO and UNICEF estimates of national infant immunization coverage: methods and processes. Bull World Heal Organ. 2009;87:535-41.

[2] Republik Indonesia Ministry of Health. Decree of the Minister of Health of the Republic of Indonesia. 2004 p. 1-40.

[3] RISKESDAS. Indonesia Basic Health Research 2013. Internet.2013. http://ghdx.healthdata.org/record/indonesia-basic-health-research2013.

[4] Anita Jutiatiningsih SS. Profil Status Imunisasi Dasar Balita di Poliklinik Umum Departemen Ilmu Kesehatan Anak Rumah Sakit Cipto Mangunkusumo Jakarta. J Sari Pediatr. 2007;9(2):121-6.

[5] Kohl KS, Marcy SM, Blum M, Jones MC, Dagan R, Hansen J, et al. Fever after immunization: current concepts and improved future scientific understanding. Clin Infect Dis. 2004;39(3):389-94.

[6] Dinarello CA. Infection, fever, and exogenous and endogenous pyrogens: some concepts have changed. J Endotoxin Res. 2004;10(4):201-22.

[7] Park B, Choi EJ, Park B, Han H, Cho SJ, Choi HJ, et al. Factors influencing vaccination in Korea: findings from focus group interviews. J Prev Med Public Heal. 2018;51(4):173.

[8] Hikmah E, Rustina Y, Pujasari H. Peningkatan Suhu Bayi Prematur Melalui Terapi Sentuhan. J Keperawatan Indones. 2011;14(3):179-84

[9] Pujiati A, Hartini S, Purnomo E. Pengaruh Terapi Sentuhan Terhadap Penurunan Suhu Tubuh Pada Bayi Usia 2-12 Bulan di Puskesmas Lebdosari Semarang. Karya Ilm. 2017;6(1).

[10] Roesli U. Pedoman Pijat Bayi Prematur dan Bayi: Usia 0-3 Bulan Cetakan ke III. Trubus Agriwidya: Jakarta. 2007;

[11] Field T, Diego M, Reif-Hernandez M. Preterm infant massage therapy research: A review. Infant Behav Dev. 2010;33(2):115-24.

[12] Dinas Kesehatan Propinsi NTB. Profil Kesehatan Propinsi NTB 2012. Nusa Tenggara Barat: Internet.https://dinkes.ntbprov.go.id/profilkesehatan/; 2012.

[13] Dinas Kesehatan Propinsi NTB. Profil Kesehatan Propinsi NTB Tahun 2015. Internet. https://dinkes.ntbprov.go.id/profil-kesehatan/.

[14] Dinas Kesehatan Kabupaten Lombok Barat. Profil Kesehatan Kabupaten Lombok Barat Tahun 2015. Internet. https://docplayer.info/35325555-Profil-kesehatan-kabupaten-lombokbarat-tahun-2015.html.

[15] Nursalam. Nursing Science Research Methodology Practical Approach. 3rd ed. Lestari PP, editor. Jakarta: Salemba Medika; 2015.

[16] Depkes RI. Modul Pelatihan Tenaga Pelaksana Imunisasi Puskesmas. Jakarta Depkes RI, Ditjen P2PL. 2006.

[17] Ramada NCO, Almeida F de A, Cunha ML da R. Toque terapêutico: influência nos parâmetros vitais de recém-nascidos. Einstein (São Paulo). 2013;11(4):421-5.

[18] Sari MP, Izzah AZ, Harmen AP. Overview of Post-Immunization
Incidents in Children Received Pertussis and Tetanus Diphtheria Immunization at the Seberang Padang Health Center in Padang City. J Kesehat Andalas. 2018;7(3):352-7.

[19] Asih SHM, Wanda D, Rustina Y. Pengaruh Perawatan Metode Kanguru Terhadap Suhu Tubuh Bayi Yang Mengalami Demam. J Ilmu Keperawatan dan Kebidanan. 2013;1(9).

[20] Firdinand, Rismarini,Yudianita Kesuma KYR. Incidence of Fever After DTwP-1 Immunization in Breastfed and Non Breastfed Children in Palembang. Sari Pediatr. 2015;17(1):52-8.

[21] Sitti Fatmayani Marhaes P, Zaenab S. Pengaruh Pemberian Imunisasi DPT Terhadap Perubahan Suhu Tubuh Pada Bayi Usia 3-12 Bulan di Puskesmas Poasiakota Kendari Provinsi Sulawesi Tenggara Tahun 2018. Poltekkes Kemenkes Kendari.Internet. http://repository.poltekkes-kdi.ac.id/id/eprint/502; 2018.

[22] Procianoy RS, Mendes EW, Silveira RC. Massage therapy improves neurodevelopment outcome at two years corrected age for very low birth weight infants. Early Hum Dev. 2010;86(1):7-11.

[23] Dalili H, Sheikhi S, Shariat M, Haghnazarian E. Infant Behavior and Development Full length article Effects of baby massage on neonatal jaundice in healthy Iranian infants : A pilot study. Infant Behav Dev. 2016;42:22-6.

[24] Ays, e Gürol, PhD, RN.Sevinç Polat, PhD R. The Effects of Baby Massage on Attachment between Mother and their Infants. Asian Nurs Res (Korean Soc Nurs Sci). 2012;6:35-41.

[25] Ummi K. Peningkatan Berat Badan Bayi Melalui Pemijatan. J Keperawatan Indones. 2014;17(1):25-9.

[26] Meliati L, Karunia Ekayani NP, Khadijah S. Effects of the Mother's Individual Stimulation on the Growth and Development of Infants with Low Birth Weight History. J Holist Nurs Midwifery. 2020;30(4):2007.

[27] Wati AM, Renityas NN. Pengaruh Pendidikan Kesehatan Tentang Pijat Bayi Terhadap Praktik Pijat Bayi. J Ners dan Kebidanan. 2014;1(1):62-7.

[28] Dwi Ernawati. Pijat Bayi Mempengaruhi Kadar Kortisol Dan Kuantitas Tidur Bayi Yang Mengalami Hospitalisasi Dengan Pendekatan Teori Comfortkolcaba. J Ilm Kesehat. 2014;7(2):138-50. 